\title{
Water balance of an Atlantic forest remnant under a prolonged drought period
}

\section{Balanço hídrico de um remanescente de Mata Atlântica em um período de seca prolongado}

\author{
André Ferreira Rodrigues ${ }^{1 *} \mathbb{D}$, Carlos Rogério de Mello ${ }^{1} \mathbb{D}$, \\ Marcela de Castro Nunes Santos Terra² ${ }^{2}$, Samuel Beskow ${ }^{3}$
}

\author{
'Universidade Federal de Lavras/UFLA, Departamento de Recursos Hídricos/DRH, Lavras, MG, Brasil \\ ${ }^{2}$ Universidade Federal de Lavras/UFLA, Departamento de Ciências Florestais/DCF, Lavras, MG, Brasil \\ 3Universidade Federal de Pelotas/UFPEL, Centro de Desenvolvimento Tecnológico/Engenharia Hídrica, Pelotas, RS, Brasil \\ ${ }^{*}$ Corresponding author: afrodrigues09@gmail.com \\ Received in April 15, 2021 and approved in May 27, 2021
}

\begin{abstract}
Since prolonged droughts have impacted Atlantic forests in Southeastern Brazil, further investigations to understand the effects of such stressful conditions in their hydrological behavior are required. This study aimed to assess the changes in the water balance of a semi-deciduous Atlantic forest remnant and how the forest responds to droughts. The Standardized PrecipitationEvapotranspiration Index was applied to identify droughts (from 1961 to 2019) and their severity in both the hydrological year and summer scales. Drought impacts on actual evapotranspiration, potential percolation, and soil water storage were assessed using Hydrus-1D, having net precipitation and potential evapotranspiration as inputs. Error analyses (<10\%) confirmed Hydrus-1D suitability for simulating soil moisture. Uncertainties regarding the soil saturated hydraulic conductivity are due to preferential flows, which are not accounted for in Richards' equation. Drought intensification changed forest hydrology and triggered physiological responses to deal with it. Semi-deciduous Atlantic forests are adapted to dry conditions because of the existence of dry-affiliated species and the activation of physiological mechanisms. However, such adaptations responded differently regarding the drought scales. The intensification of summer droughts increased evapotranspiration and decreased the potential percolation. Leaf shedding changed the canopy structure in a two-year time lag as a response to the intensification of hydrological year droughts. Changes in forest hydrology are sudden and trigger physiological responses, such as leaf shedding, in a delayed process after droughts take place.
\end{abstract}

Index terms: Semi-deciduousness; SPEl; soil moisture modeling; evapotranspiration; potential percolation.

\section{RESUMO}

Períodos de seca prolongados têm impactado as florestas Atlânticas no sudeste do Brasil, demandando investigações para entender os efeitos destas condições estressantes em sua hidrologia. Este estudo objetivou avaliar as mudanças no balanço hídrico de um remanescente de floresta Atlântica semi-decidual e como ela responde à secas. O Índice Padronizado Precipitação-Evapotranspiração (SPEI) foi aplicado para identificar os períodos de seca (de 1961 a 2019) e suas severidades nas escalas de ano hidrológico e verão. Os impactos das secas na evapotranspiração real, na percolação potencial e no armazenamento de água no solo foram analisados por meio do Hydrus-1D, considerando a precipitação efetiva e a evapotranspiração potencial como entradas. As análises de erro (< 10\%) confirmaram a adequabilidade do Hydrus-1D na simulação da umidade do solo. Incertezas com relação à condutividade hidráulica saturada estão relacionadas à presença de caminhos preferenciais, os quais não são considerados na equação de Richards. $\mathrm{A}$ intensificação das secas acarretaram mudanças na hidrologia florestal, ativando respostas fisiológicas. Florestas Atlânticas semi-deciduais são adaptadas a períodos secos devido à suas espécies adaptadas e à ativação de mecanismos fisiológicos. No entanto, a floresta respondeu de maneira diferente considerando as escalas de seca. A intensificação das secas no verão aumentou a evapotranspiração e diminuiu a percolação potencial. A perda de folhas alterou a estrutura do dossel em um intervalo de dois anos em resposta à intensificação da seca no ano hidrológico. Alterações na hidrologia florestal ativam respostas fisiológicas (como a perda de folhas) em um processo atrasado após episódios de seca.

Termos para indexação: Semi-deciduidade; SPEl; modelagem da umidade do solo; evapotranspiração; percolação potencial. 


\section{INTRODUCTION}

The conservation of natural environments is crucial to improve the longevity of water supply for ecological, environmental, and socioeconomic needs. It has become even more essential in the face of more frequent and severe droughts (Junqueira et al., 2020). Southeastern Brazil has faced drier years recently (Coelho et al., 2016), which increased water conflicts and impaired people's well-being and livelihood. Atlantic forests have been considered to improve groundwater recharge and water yield (Mello et al., 2019) since they are properly managed (Teixeira et al., 2021). However, the impacts of severe droughts on Atlantic forests' hydrology have not been adequately addressed. Therefore, studies concerning the water balance under drought conditions are urgent.

It is well-known that some tropical species activate physiological mechanisms (e.g., leaf shedding and deep water uptake) as drought conditions tend to become more acute in tropical regions (Broedel et al., 2017; Markewitz et al., 2010; Williams; Bunyavejchewin; Baker, 2008). This is the case of semi-deciduous Atlantic forests, in which up to $50 \%$ of the species lose their leaves in rainless periods (Terra et al., 2018). However, the intensification of droughts can trigger tree mortality (Rowland et al., 2015; Zhang et al., 2017) and shift species to those more adapted to drier conditions (Aguirre-Gutiérrez et al., 2019). These aspects have been thoroughly investigated because of the importance of tropical forests to mitigate climate change effects (Anderegg et al., 2020). However, changes in forest structure are likely due to changes in its hydrological behavior. Drought conditions increase the turbulent mechanisms (e.g., advection from surrounding areas), increasing the evapotranspiration and decreasing water availability (Rodrigues et al., 2021).

Therefore, defining droughts' onset, intensity, frequency, and duration are mandatory to couple with the climate changes expected for Southeastern Brazil (Oliveira et al., 2017), which will impact Atlantic forests' water dynamics. The widespread Standardized Precipitation Index (SPI) relies on the analysis of a rainfall dataset through a normalized probability distribution function (Junqueira et al., 2020). Nevertheless, the impacts of droughts on forests are beyond changes in rainfall patterns. The forest connects atmosphere and soil through root water uptake and gas exchanges on the canopy (i.e. carbon uptake and transpiration), forming the soil-plant-atmosphere continuum. Therefore, evapotranspiration should also be accounted for in drought characterization in forest systems. The Standardized Precipitation-Evapotranspiration Index
(SPEI) has been preferred for studying the impacts on forests (Aguirre-Gutiérrez et al., 2019; Zhang et al., 2017) as it assembles the effects of rainfall and evapotranspiration on drought characterization (Vicente-Serrano; Beguería; López-Moreno, 2010).

The hydrology of Atlantic forests have been mainly assessed in watershed scales (Mello et al., 2019; Teixeira et al., 2021) since remote sensing information and automatic streamflow monitoring can be applied. However, field studies are crucial to assess and model the soil-plantatmosphere continuum, which aids in the understanding of the impacts of droughts on forest hydrology. The greatest challenge of modeling this process is the feasibility of parametrization, which is laborious and time-consuming. Alternatively, some studies have used the inverse functions to determine soil hydraulic parameters since they require measured hydrological variables under field conditions (Šimunek; Van Genuchten; Šejna, 2008). In this sense, the Hydrus software has been widely implemented with suitable results in different environments (Chen; Willgoose; Saco, 2014). Hydrus performs a water balance in one, two, or three dimensions, having the soil as the control volume (Šimunek; Van Genuchten; Šejna, 2008), in which percolation, evapotranspiration, and soil water storage can be assessed. Drought effects on both rainfall and evapotranspiration are accounted for in Hydrus' framework. In this study, we relied on the one-dimension version (Hydrus-1D) since most of the water movement is likely to occur in the vertical direction due to the high drainage capacity of the Oxidic Latosol (Junqueira Junior et al., 2017).

The studied Atlantic forest remnant is in an advanced successional stage (Souza et al., 2021), agreeing with the considerations about forest development for water yield purposes (Teixeira et al., 2021). In this regard, this study aimed to: (i) assess the impact of droughts on the water balance components of a semi-deciduous Atlantic forest remnant; and (ii) track the forest's physiological responses to deal with severe droughts. The results from this study aid to elucidate the impacts of stressful scenarios on the Atlantic forest remnant's hydrology and support decision-makers on the upcoming climate change scenarios (Oliveira et al., 2017).

\section{MATERIAL AND METHODS}

\section{Study area and data collections}

This study was carried out in a semi-deciduous seasonal Atlantic forest remnant of 6.35 ha, located on the coordinates $44^{\circ} 58^{\prime} 15^{\prime \prime} \mathrm{W}$ and $21^{\circ} 13^{\prime} 42^{\prime \prime} \mathrm{S}$ in Minas 
Gerais state, Brazil. The soil of the studied site is an Oxidic Latosol, characterized by great porosity and high soil saturated hydraulic conductivity (Junqueira Junior et al., 2017). The phenological classification of the forest is "semi-deciduous forest" because up to $50 \%$ of the species lose their leaves during the dry season (Terra et al., 2018). The Köppen-type climate of the region is Cwa, which is characterized by rainy summers and dry winters. The wet season is between October and March, whereas the dry season comprehends April to September. The mean annual precipitation and potential evapotranspiration are 1462 and $1254 \mathrm{~mm}$, respectively, and the mean annual temperature is $20.3{ }^{\circ} \mathrm{C}$, ranging from $16.9{ }^{\circ} \mathrm{C}$ in July to $22.8{ }^{\circ} \mathrm{C}$ in February (long-term averages, access link: https://portal. inmet.gov.br/normais).

Inside the forest stand, nine monitoring sets were selected to monitor throughfall, stemflow, and soil moisture (Figure 1). Throughfall was collected using "Ville de Paris" rain gauges installed at $1.50 \mathrm{~m}$ above the ground with a catching area of $378.5 \mathrm{~cm}^{2}$. A hose slit to the length was nailed to the trunk and sealed with silicone to drain the water running down the trunk (i.e., stemflow) into a vessel (Terra et al., 2018). Soil moisture measurements were carried out through a Profile Probe (PR2/6 capacitance probe, Delta-T Devices, Cambridge, UK) at the depths of $0.10 ; 0.20 ; 0.30 ; 0.40$, and $1.0 \mathrm{~m}$, to observe the water redistribution in the soil profile. Air temperature, wind velocity and direction, solar radiation, and air humidity were automatically monitored above the canopy (on a 22-m meteorological tower) in a Campbell Scientific CR10X weather station set in an hourly step. A "Ville de Paris" rain gauge was also installed on the tower to monitor the gross precipitation (GP).

The monitoring period spans from January 2013 to December 2018. Gross precipitation, throughfall, stemflow, and soil moisture were manually measured in the following day after each rainfall event. Throughfall and stemflow were integrated for each event to account for net precipitation, which represents the gross rainfall portion that reaches the forest floor. Moreover, daily field campaigns were performed in January and February 2018 to improve Hydrus calibration. These campaigns were set to monitor the daily soil moisture variability as these months represent $33 \%$ of the annual rainfall.

\section{The Standardized Precipitation-Evapotranspiration Index (SPEI)}

To demonstrate that the studied period (20132018) was the driest observed since the 1960s, a multiscale drought index, the Standardized Precipitation-
Evapotranspiration Index (SPEI), was applied (VicenteSerrano; Beguería; López-Moreno, 2010). Its calculation is based on a time series of vertical water balance, which is determined by the difference between rainfall and potential evapotranspiration in a given period. In the SPEI, the log-logistic theoretical distribution is fitted to the vertical water balance time series (VicenteSerrano; Beguería; López-Moreno, 2010). For assessing the goodness-of-fit of the log-logistic distribution, the Anderson-Darling test (Anderson; Darling, 1952, $1954)$ at $5 \%$ of significance was applied. After that, the inverse of the Gauss distribution is applied to the non-exceedance probabilities and the resulting values correspond to the SPEI.

Drought conditions were assessed for two temporal scales: the hydrological year (October to September) and summer (December to February). Such scales aimed to highlight the long and short effects of droughts on the forest water balance. Thus, the SPEI calculations relied on the time series of monthly precipitation and average temperature from 1961 to 2019 of the "Instituto Nacional de Meteorologia-INMET". The INMET weather station is one $\mathrm{km}$ from the Atlantic forest stand. The potential evapotranspiration for the SPEI was calculated through the Thornthwaite method (Vicente-Serrano; Beguería; López-Moreno, 2010).

\section{Soil moisture modeling: boundary and initial conditions}

Richards' equation was solved in Hydrus-1D for soil moisture prediction (Equation 1) (Šimunek; Van Genuchten; Šejna, 2008):

$\frac{\partial \theta}{\partial \mathrm{t}}=\frac{\partial}{\partial \mathrm{z}}\left[\mathrm{K}(\theta)\left(\frac{\partial \mathrm{h}(\theta)}{\partial \mathrm{z}}+1\right)\right]-\mathrm{S}\left(\mathrm{h}, \mathrm{h}_{\varphi}, \mathrm{z}\right)$

where $\theta$ is the volumetric water content $\left[\mathrm{cm}^{3} \mathrm{~cm}^{-3}\right] ; \mathrm{K}$ is the unsaturated soil hydraulic conductivity $\left[\mathrm{cm} \mathrm{day}^{-1}\right]$; $h$ is the pressure head $[\mathrm{cm}] ; h_{\phi}$ is the soil osmotic head $[\mathrm{cm}] ; \mathrm{z}$ is the spatial coordinate (positive upward) $[\mathrm{cm}]$; $\mathrm{S}$ is the soil-water uptake by the root system $\left[\right.$ day $\left.^{-1}\right]$; and $\mathrm{t}$ is the time [day].

The boundary conditions assumed on the surface were net precipitation and evapotranspiration with immediate runoff (Equations 2 and 3). Free drainage was considered as the boundary condition in the soil profile bottom due to the water table depth (very deep soil - without either water table influence or significant sub-surface flow). 
$\left|\mathrm{K}(\mathrm{h})\left(\frac{\partial \mathrm{h}}{\partial \mathrm{z}}+1\right)\right| \leq \mathrm{E}$

$\mathrm{h}_{\mathrm{a}} \leq \mathrm{h} \leq \mathrm{h}_{\mathrm{s}}$ where $\mathrm{E}$ is the maximum potential infiltration or evaporation rate for the current atmospheric condition $\left[\mathrm{cm}\right.$ day $\left.^{-1}\right] ; \mathrm{h}$ and $\mathrm{h}$ are, respectively, the maximum and minimum surface hydraulic head, which depends on the

soil characteristics $[\mathrm{cm}]$.

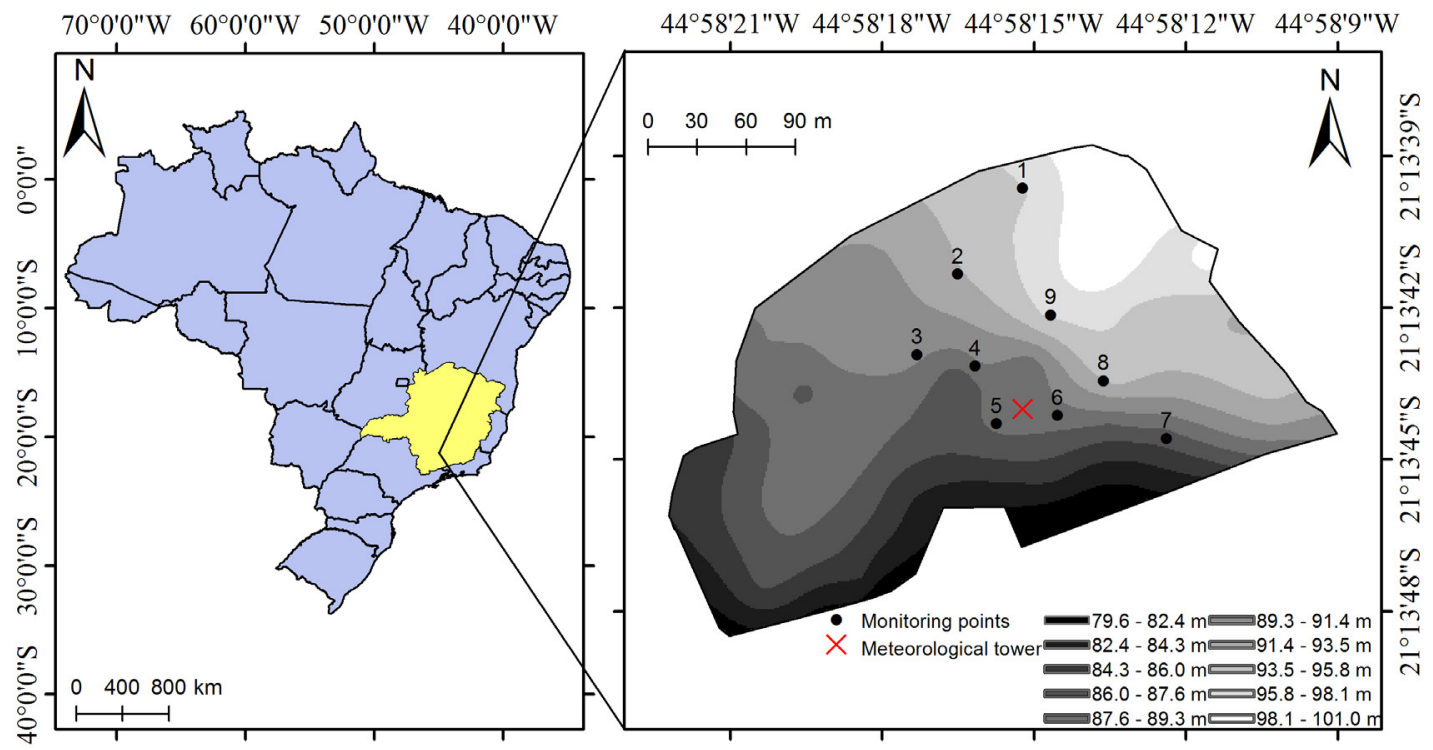

a)

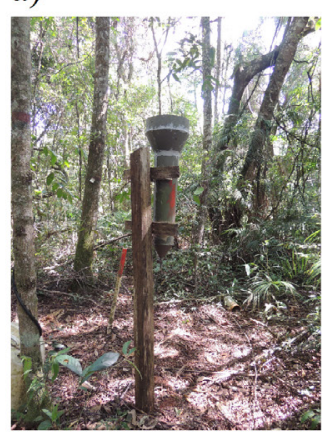

b)

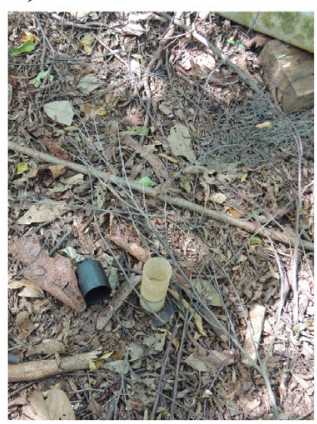

c)

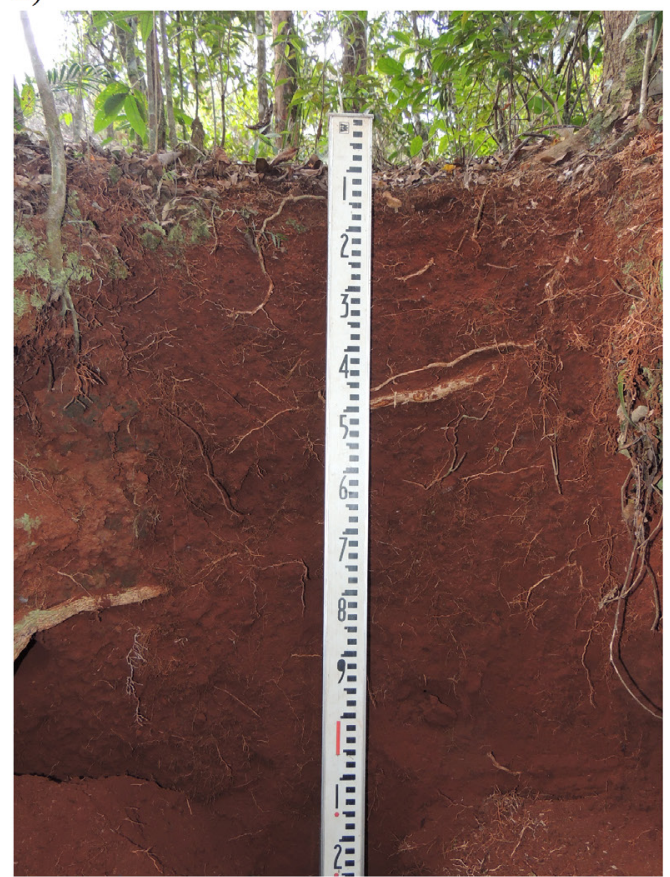

d)

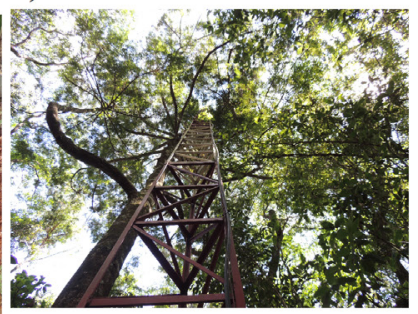

e)

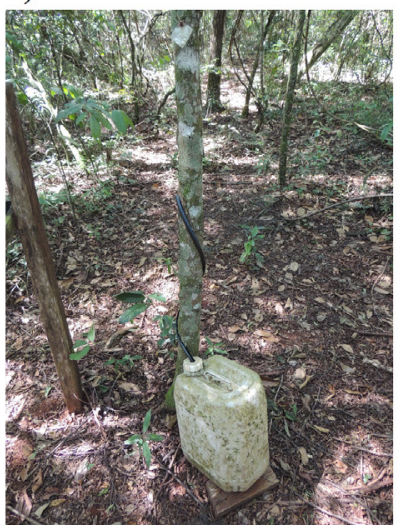

Figure 1: Geographical location, spatial distribution of the monitoring sets, and topography of the Atlantic forest stand: A: "Vile de Paris" rain gauge; B: tube for soil moisture measurement down to $1.0 \mathrm{~m}$ depth; C: Oxidic Latosol profile; D: meteorological tower; E: stemflow apparatus. 
As the model requires that the soil moisture is known before starting the simulation, the initial condition was set as the linear interpolation of $0.10 ; 0.20 ; 0.30$; 0.40 , and $1.0 \mathrm{~m}$ depths of the first soil moisture reading in January 2018.

\section{Root water uptake}

The van Genuchten S-shaped model was applied to account for the root water uptake (Equation 4) (van Genuchten, 1987):

$\mathrm{S}\left(\mathrm{h}, \mathrm{h}_{\varphi}, \mathrm{z}\right)=\mathrm{a}\left(\mathrm{h}, \mathrm{h}_{\varphi}\right) \mathrm{b}(\mathrm{z}) \mathrm{T}_{\mathrm{P}}$

where $\mathrm{h}_{\phi}$ is the soil water osmotic head $[\mathrm{cm}] ; \mathrm{b}(\mathrm{z})$ the normalized water uptake distribution $\left[\mathrm{cm}^{-1}\right] ; \mathrm{T}_{\mathrm{P}}$ is the potential transpiration $\left[\mathrm{cm} \mathrm{day}^{-1}\right]$; and $\mathrm{a}\left(\mathrm{h}, \mathrm{h}_{\phi}\right)$ is the root water uptake stress function given by van Genuchten (1987) (Equation 5):

$$
\mathrm{a}\left(\mathrm{h}, \mathrm{h}_{\varphi}\right)=\frac{1}{1+\left(\frac{\mathrm{h}+\mathrm{h}_{\varphi}}{\mathrm{h}_{50}}\right)^{\mathrm{P}}}
$$

where $\mathrm{P}$ is an experimental constant; $\mathrm{h}_{50}$ is the pressure head, in which root water uptake is reduced by $50 \%$ when negligible osmotic stress occurs. The S-shaped parameters used in the modeling were $\mathrm{P}=3$ and $\mathrm{h}_{50}=$ $-800 \mathrm{~cm}$ (van Genuchten, 1987). During the installation of the profile tubes, it was observed a decrease of fine roots down to $1.10 \mathrm{~m}$ depth. In this regard, a linear distribution was selected to normalize the soil-water uptake throughout this profile with greater roots' concentration on the surface layers.

In Atlantic forests, a significant portion of the evaporation occurs through canopy interception (Junqueira Junior et al., 2019; Rodrigues et al., 2021), which was previously extracted when considering net precipitation as the input variable. Thus, the potential root water uptake integrated along the $1.10 \mathrm{~m}$ soil profile is the potential transpiration $\left(\mathrm{T}_{\mathrm{p}}\right)$. Beer's Law (Equation 6) was applied to separate potential evapotranspiration (PET) into potential transpiration and evaporation $\left(\mathrm{E}_{\mathrm{p}}\right)$.

$\mathrm{T}_{\mathrm{P}}=\operatorname{PET}\left(1-\exp ^{(-\mathrm{r} \times \mathrm{LAI})}\right)$

where $r$ is the extinction coefficient; and LAI refers to the leaf area index $\left(\mathrm{m}^{2} \mathrm{~m}^{-2}\right)$, which was measured monthly between April/2013 and March/2014 at the nine points by means of a canopy analyzer LAI-2000 (Li-Cor $\left.{ }^{\circledR}\right)$. The potential evapotranspiration was determined by the FAO 56 Penman-Monteith equation (Equation 7) (Allen et al., 1998):

$P E T=\frac{0.408 * \Delta R_{n}+\frac{\gamma * 900 * u_{2} *\left(e_{s}-e_{a}\right)}{(T+273)}}{\Delta+\gamma *\left(1+0.34 * u_{2}\right)}$

where $\mathrm{R}_{\mathrm{n}}$ is the net radiation above the canopy [MJ m${ }^{-2}$ day $\left.^{-1}\right] ; \mathrm{e}_{\mathrm{s}}$ and $\mathrm{e}_{\mathrm{a}}$ are the saturation and actual air vapor pressure, respectively $[\mathrm{kPa}] ; \Delta$ is the vapor pressure curve slope $\left[\mathrm{kPa}^{\circ} \mathrm{C}^{-1}\right] ; \gamma$ is the psychrometric constant $\left[\mathrm{kPa}^{\circ} \mathrm{C}^{-1}\right]$; $\mathrm{u}_{2}$ is the wind velocity at $2 \mathrm{~m}$ height $\left[\mathrm{m} \mathrm{s}^{-1}\right]$; and $\mathrm{T}$ is the daily mean air temperature $\left[{ }^{\circ} \mathrm{C}\right]$.

\section{Hydrus-1D calibration and validation}

The van Genuchten-Mualem parameters (Equations 8 and 9) were inversely determined minimizing the objective function using the Levenberg-Marquardt non-linear approach (Šimunek; Van Genuchten; Šejna, 2008). The inverse solution searches for the best soil hydrological parameters that minimize the differences between the observed and simulated data. For this, a daily soil moisture dataset from January to February 2018 was used. Thereafter, the model was validated comparing the simulated and observed soil moisture from January 2016 to December 2017.

$\theta=\theta_{r}+\frac{\left(\theta_{s}-\theta_{r}\right)}{\left[1+|\alpha h|^{n}\right]^{m}}$

$\mathrm{K}\left(\mathrm{S}_{\mathrm{e}}\right)=\mathrm{Ks} \times \mathrm{S}_{\mathrm{e}}^{1} \times\left[1-\left(1-\mathrm{S}_{\mathrm{e}}^{1 / \mathrm{m}}\right)^{\mathrm{m}}\right]^{2}$

where $\theta_{\mathrm{r}}$ is the residual soil moisture $\left[\mathrm{cm}^{3} \mathrm{~cm}^{-3}\right] ; \theta_{\mathrm{s}}$ is the saturation soil moisture $\left[\mathrm{cm}^{3} \mathrm{~cm}^{-3}\right] ; \alpha$ is an empirical parameter inversely related to the air entrance pressure $\left[\mathrm{cm}^{-1}\right] ; \mathrm{n}$ is the pore size distribution $[-] ; 1$ is the parameter related to porous tortuosity and connectivity, fixed as 0.5 (Mualem, 1976) [-]; Ks is the soil saturated hydraulic conductivity $\left[\mathrm{cm} \mathrm{day}^{-1}\right] ; \mathrm{S}_{\mathrm{e}}=\left(\theta-\theta_{\mathrm{r}}\right) /\left(\theta_{\mathrm{s}}-\theta_{\mathrm{r}}\right)$ is the effective saturation $[-]$; and $\mathrm{m}=1-(1 / \mathrm{n})$ (van Genuchten, 1980).

Soil moisture modeling was run in a profile of 1.10 $\mathrm{m}$, stratified in 201 nodal points with a greater density in 
the surface to improve the numerical solution. The profile was split in $0-0.15 ; 0.15-0.25 ; 0.25-0.35 ; 0.35-0.45$; and $0.45-1.10 \mathrm{~m}$ layers, in which the soil hydraulic parameters were determined following the methodology proposed by Turkeltaub et al. (2015). The initial parameters were taken from Lucas et al. (2011).

\section{Uncertainty statistics for Hydrus-1D validation}

Relative error (RE), root mean squared error (RMSE), and the Nash-Sutcliffe coefficient (NS) were applied to assess the performance of the simulation with Hydrus-1D (Equations 10, 11, and 12, respectively). Values of RE and RMSE closer to zero mean an adequate fit; $\mathrm{NS}=1$ represents a perfect model; $\mathrm{NS}=0$ indicates that the simulated values are as accurate as the average of the observed soil moisture values; and for NS $<0$, simulated values are less accurate than the average of the observed soil moisture.

$R E=\frac{1}{N} \sum_{i=1}^{N} \frac{\left|P_{i}-O_{i}\right|}{O_{i}}$

$R M S E=\sqrt{\frac{1}{N} \sum_{i=1}^{N}\left(P_{i}-O_{i}\right)^{2}}$

$N S=1-\frac{\sum_{i=1}^{N}\left(P_{i}-O_{i}\right)^{2}}{\sum_{i=1}^{N}\left(O_{i}-O_{m}\right)^{2}}$

where $\mathrm{P}_{\mathrm{i}}$ and $\mathrm{O}_{\mathrm{i}}$ are the $\mathrm{i}$-th simulated and observed soil moisture, respectively; $\mathrm{N}$ is the number of simulated and observed pair values; and $\mathrm{O}_{\mathrm{m}}$ is the average of the observed soil moisture.

\section{Water balance and soil moisture dynamics evaluation}

Hydrus-1D performs a water balance in the soil profile, modeling the potential percolation (PP), actual evapotranspiration (Etr), soil water storage (SWS), and runoff generation. After calibration and validation, Hydrus-1D was run from October 2013 to September 2018 to assess the impact of recent drought conditions on these hydrological variables. For this, 2013 (up to September) was set as the warm-up period to avoid issues regarding initial moisture conditions.

\section{RESULTS AND DISCUSSION}

\section{Hydrological behavior of the Atlantic forest remnant}

The gross precipitation ranged from $876 \mathrm{~mm}$ to $1374 \mathrm{~mm}$ (2014 and 2013, respectively), being all below the long-term average $(1462 \mathrm{~mm})$. The canopy interception accounted for $22.7 \%$, which is close to those obtained by Ávila et al. (2014) for an Atlantic forest biome in the Mantiqueira range. Canopy interception ranged from $19.2 \%$ to $31.5 \%$ and from $12.4 \%$ to $42.2 \%$ for wet and dry seasons, respectively, following the rainfall pattern of the region (Rodrigues et al., 2021). Such a behavior drives the soil moisture dynamics, governs the water input to the forest floor, and affects the water balance.

Soil moisture increased with depth (KruskalWallis test, $\mathrm{p}$-value $<0.0001)$ and presented greater variability at $0.1 \mathrm{~m}$ and $1.0 \mathrm{~m}$ depths (Table 1 ). Moreover, the net precipitation ranged from 0 to $73.2 \mathrm{~mm}(14.8$ $\mathrm{mm} \pm 15.5 \mathrm{~mm}$ ) across the monitoring sets with a significant spatial variability (Table 2 ). The scattered canopy with three distinguished layers summed to the species diversity (Terra et al., 2018) cause heterogeneity on the rainfall partitioning, and therefore drive the spatial variability of net precipitation (Rodrigues et al., 2020). The different water inputs are the main cause of the soil moisture variability observed at $0.1 \mathrm{~m}$ depth since throughfall is the main hydrological variable driving the spatiotemporal pattern of soil moisture in this forest (Oliveira et al., 2021). On the other hand, the variability at $1.0 \mathrm{~m}$ depth has been related to the soil saturated hydraulic conductivity (Junqueira Junior et al., 2017), which is influenced by preferential pathways in forested sites. Preferential pathways play a significant role in soil water redistribution, increasing soil moisture spatiotemporal variability and favoring groundwater recharge (Zhang et al., 2016).

\section{Hydrus-1D calibration and validation under field conditions}

The precision statistics (Table 3 ) indicated a satisfactory performance of Hydrus-1D in both calibration and validation. These values are in accordance with other studies that have applied the inverse methodology under field conditions (Chen; Willgoose; Saco, 2014). Taking ER, RMSE, and NS, Hydrus-1D performed reasonably well the soil moisture dynamics, showing good agreement between the observed and simulated data with errors $<10 \%$. 
Table 1: Net precipitation and soil moisture mean, standard deviation, and coefficient of variation (CV) in the daily field campaign (January and February 2018).

\begin{tabular}{|c|c|c|c|}
\hline & Mean & Standard deviation & CV $(\%)$ \\
\hline Net precipitation (mm) & 14.8 & 15.5 & 104 \\
\hline $0.1 \mathrm{~m}\left(\mathrm{~cm}^{3} \mathrm{~cm}^{-3}\right)$ & 0.2764 & 0.0241 & 8.7 \\
\hline $0.2 \mathrm{~m}\left(\mathrm{~cm}^{3} \mathrm{~cm}^{-3}\right)$ & 0.3018 & 0.0186 & 6.2 \\
\hline $0.3 \mathrm{~m}\left(\mathrm{~cm}^{3} \mathrm{~cm}^{-3}\right)$ & 0.2955 & 0.0185 & 6.3 \\
\hline $0.4 \mathrm{~m}\left(\mathrm{~cm}^{3} \mathrm{~cm}^{-3}\right)$ & 0.3100 & 0.0195 & 6.3 \\
\hline $1.0 \mathrm{~m}\left(\mathrm{~cm}^{3} \mathrm{~cm}^{-3}\right)$ & 0.3340 & 0.0336 & 10.1 \\
\hline
\end{tabular}

Table 2: Drought severity classification for the hydrological year and summer scales according to the World Meteorological Organization.

\begin{tabular}{ccccc}
\hline Period & Summer & Classification & Hydrological year & Classification \\
\hline $2013-2014$ & -1.78 & Severe drought & -1.85 & Severe drought \\
$2014-2015$ & -1.37 & Moderate drought & -1.44 & Moderate drought \\
$2015-2016$ & -0.01 & Near normal & -0.74 & Near normal \\
$2016-2017$ & -2.02 & Extreme drought & -1.40 & Moderate drought \\
$2017-2018$ & -0.99 & Near normal & -1.60 & Severe drought \\
\hline
\end{tabular}

Table 3: Relative error (RE), root mean squared error (RMSE), and the Nash-Sutcliffe coefficient (NS) for Hydrus-1D calibration (January to February 2018) and validation (January 2016 to December 2017) in the Atlantic forest remnant.

\begin{tabular}{ccccccc}
\hline \multirow{2}{*}{ Sets } & \multicolumn{3}{c}{ Calibration } & \multicolumn{3}{c}{ Validation } \\
\cline { 2 - 6 } & $\mathrm{NS}$ & $\mathrm{RE}$ & $\mathrm{RMSE}\left(\mathrm{cm}^{3} \mathrm{~cm}^{-3}\right)$ & $\mathrm{NS}$ & $\mathrm{RE}$ & $\mathrm{RMSE}\left(\mathrm{cm}^{3} \mathrm{~cm}^{-3}\right)$ \\
\hline 1 & 0.80 & 0.0378 & 0.0155 & 0.41 & 0.0670 & 0.0240 \\
2 & 0.46 & 0.0319 & 0.0157 & 0.23 & 0.0504 & 0.0166 \\
3 & 0.85 & 0.0309 & 0.0130 & 0.47 & 0.0479 & 0.0209 \\
4 & 0.75 & 0.0271 & 0.0101 & 0.27 & 0.0402 & 0.0148 \\
5 & 0.82 & 0.0274 & 0.0121 & 0.58 & 0.0414 & 0.0156 \\
6 & 0.62 & 0.0340 & 0.0130 & 0.46 & 0.0430 & 0.0162 \\
7 & 0.68 & 0.0291 & 0.0142 & 0.63 & 0.0368 & 0.0138 \\
8 & 0.74 & 0.0288 & 0.0111 & 0.34 & 0.0515 & 0.0178 \\
9 & 0.34 & 0.0381 & 0.0160 & 0.37 & 0.0457 & 0.0177 \\
\hline
\end{tabular}

The final parameters for each site and layer are presented in Figure 2. The first important observation is related to the calibrated values of the saturation soil moisture $\left(\theta_{\mathrm{s}}\right)$. Values greater than $0.40 \mathrm{~cm}^{3} \mathrm{~cm}^{-3}$ were not achieved, even though Oxidic Latosols are characterized by great porosity (Braga et al., 2013). The time-lag between the soil moisture monitoring and rainfall occurrence impaired the calibration of the saturation moisture $\left(\theta_{\mathrm{s}}\right)$, showing that a daily resolution is not sufficient to capture the gravitational water movement throughout the $1.0 \mathrm{~m}$ depth profile. On the other hand, the values of $\alpha$ and $n$ are following the literature and represent the variability of macro and micro-pores (Braga et al., 2013), highlighting the granular structure and holding water capacity of the Oxidic Latosols. 

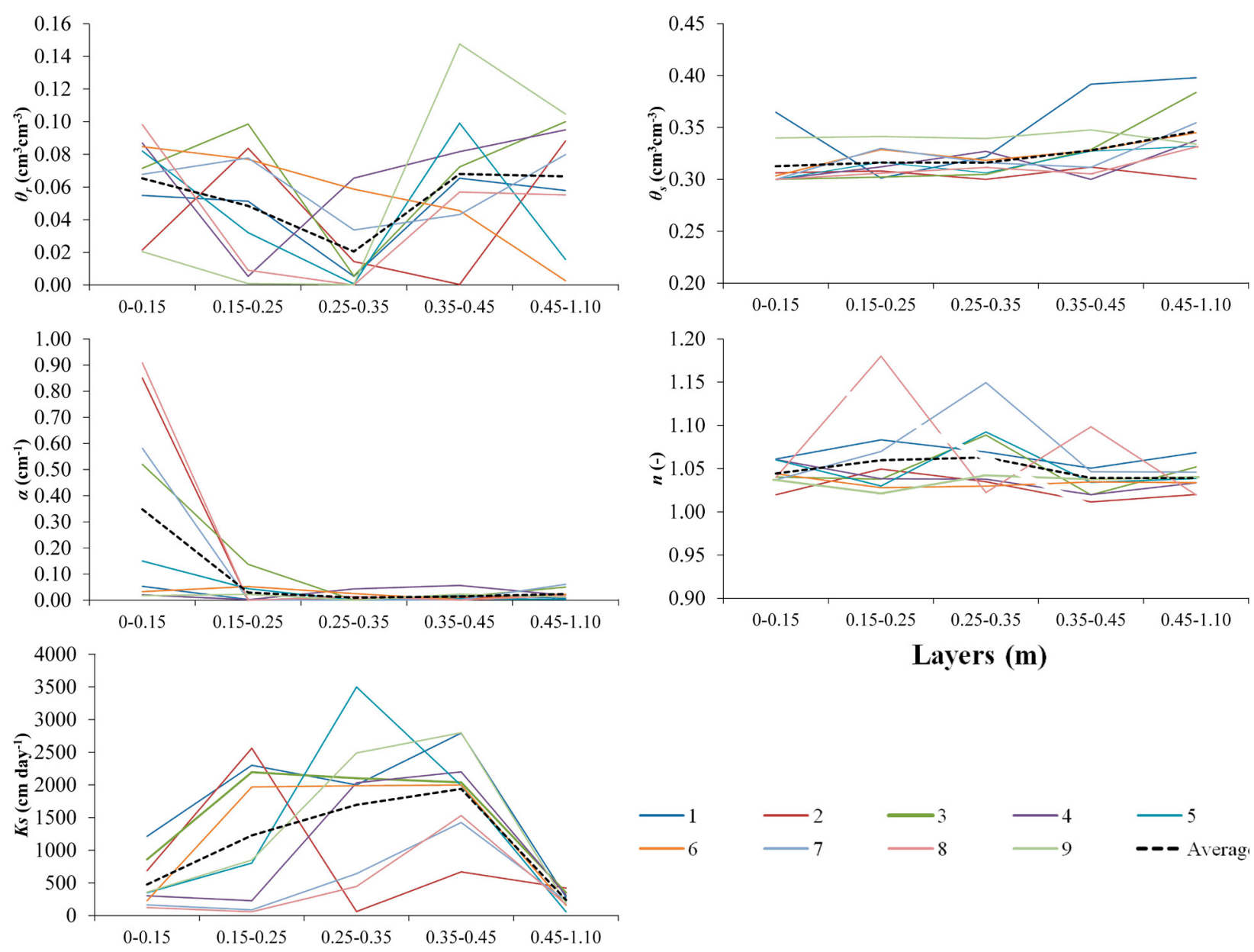

\section{Layers (m)}

Figure 2: Spatial and vertical variability of the calibrated van Genuchten parameters at the five layers. $\theta_{r}$ : residual soil moisture; $\alpha$ : empirical parameter inversely related to the air entrance pressure, Ks: soil saturated hydraulic conductivity, $\theta_{\mathrm{s}}$ : saturation soil moisture, $\mathrm{n}$ : pore size distribution.

Uncertainties could be observed in both the soil saturated hydraulic conductivity (Ks) and residual soil moisture $\left(\theta_{\mathrm{r}}\right)$. Although there was some uncertainty in $\theta_{\mathrm{r}}$ (Figure 2), Hydrus-1D is more sensitive to Ks, $\theta_{\mathrm{s}}$, and $\mathrm{n}$ than to the other parameters (Ventrella et al., 2019). Thus, the uncertainty of $\theta_{\mathrm{r}}$ is not concerning to the simulation results. Regarding Ks, the uncertainties were mostly on the shallower depths (up to $0.45 \mathrm{~m}$ ). The greater density of roots and organic matter (Salemi et al., 2013) favor the formation of preferential pathways in these depths, which are likely the cause of such uncertainties. Preferential flows are not accounted for in the simple form of Richard's equation (Equation 1), which considers a uniform flow without splitting the water movement between the preferential pathways and pores (Šimunek et al., 2003). However, the calibrated values of the first layer are in accordance with those determined by Junqueira Junior et al. (2017), who used a Guelph permeameter device for Ks determination at the same site. This highlights the suitability of Hydrus-1D to simulate the fast processes (e.g., infiltration) (Chen; Willgoose; Saco, 2014), performing better in the shallower depths and providing more reliable parameters.

It is worth mentioning that there are further sources of uncertainty in modeling the soil-plantatmosphere continuum. First, the great plant diversity of Atlantic forests, with roots at different ages, shapes, sizes, and water demand, difficult the models' parameterization, which leads to uncertainties in the simulated water uptake and forest transpiration (Terra et al., 2017). Second, the importance of topography on the spatiotemporal dynamics of soil moisture (Oliveira et al., 2021) is not 
accounted for in the Hydrus-1D version. Although it seems that the water movement was predominantly in the vertical direction, part of the moisture is likely moving in other directions than vertical. In this regard, future studies should evaluate the performance of Hydrus $2 \mathrm{D}$ and $3 \mathrm{D}$ since the topography can be integrated into the modeling. Nevertheless, Hydrus-1D presented an adequate performance (Table 3 ) with the calibrated parameters in agreement with the current literature.

\section{The Standardized Precipitation-Evapotranspiration Index (SPEI)}

The Anderson-Darling test ( $p$-value $<0.05$ ) indicated an adequate fit of the log-logistic distribution to the studied datasets (hydrological year and summer scales). Therefore, the SPEI can be applied to assess the droughts that have hit the study region. The Atlantic forest remnant has faced drought conditions regarding both the hydrological (Figure 3a) and summer (Figure 3b) scales in the last 60 years. From 2012-2013 to 2017-2018 hydrological years, a prolonged drought could be observed being 2013-2014 and 2017-2018 severely dry hydrological years and the summer of 2016-2017, the driest since 1961 . Coelho et al. (2016) stressed the magnitude of the drought of 2013-2014 and its impact on the water resources in Southeastern Brazil.

The drought severity spanning the study period can be classified according to the World Meteorological Organization (World Meteorological Organization WMO, 2012) (Table 2). Although Souza et al. (2021) assessed the drought severity in the study site, they did not evaluate its impacts on the water balance neither classified its severity. Further, they did not evaluate other drought scales such as the summer scale.

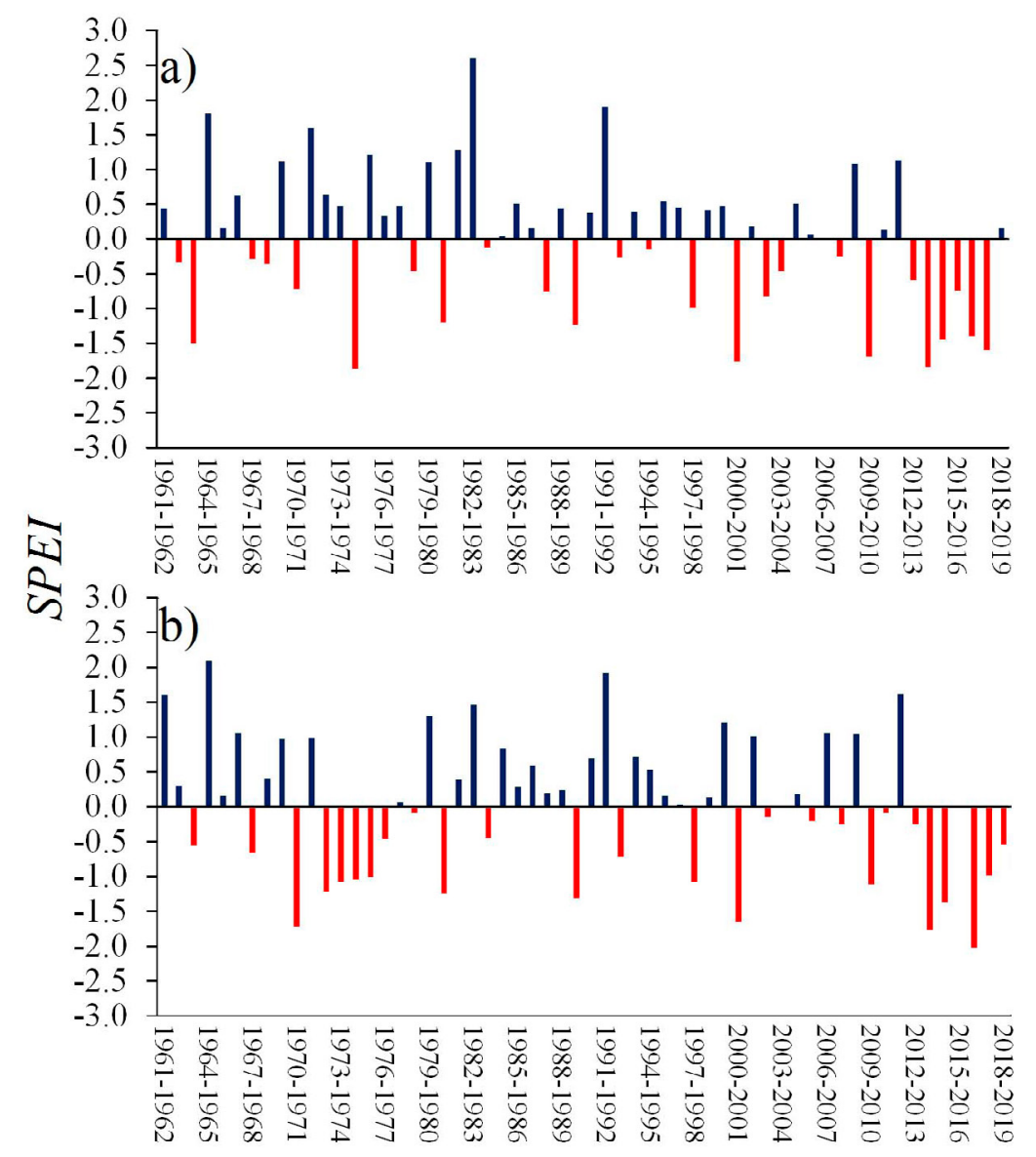

Figure 3: The Standardized Precipitation-Evapotranspiration Index (SPEI) calculated for (A) the hydrological year and (B) summer scales from 1961 to 2019 in the studied site. Blue bars are positive SPEI and red bars are negative SPEI. 


\section{Water balance assessment}

Surface runoff was lower than $0.1 \%$ of gross precipitation, showing the previous assumption that surface runoff in the Atlantic Forest remnant is negligible. Thus, the most significant hydrological variables were the actual evapotranspiration, the potential percolation, and the variation in soil water storage.

\section{Actual evapotranspiration (Etr)}

Figure 4 depicts the seasonality of the hydrological variables, from which actual evapotranspiration (Etr) reaches the highest values in the wet season due to the greater availability of water and energy. However, it is worth noting that a decrease in Etr occurs during the driest months in the wet season. This is partly due to the sensitivity of soil water storage to net precipitation, i.e., a month with low net precipitation (e.g., February/2014, January/2015, October/2015, and February/2016) causes a decrease in soil water storage, which affects evapotranspiration. During the dry season, evapotranspiration is driven by the fluctuation in both soil water storage and net precipitation. This is highlighted in the dry seasons (from July to September) of 2014, 2015 , and 2018, in which the net precipitation was 59.1 $\mathrm{mm}, 129.2 \mathrm{~mm}$, and $92.1 \mathrm{~mm}$, respectively, whereas the actual evapotranspiration was $42.2 \mathrm{~mm}, 51.4 \mathrm{~mm}$, and
$53.6 \mathrm{~mm}$, respectively. Nevertheless, for the same period of 2017 , the net precipitation was only $0.9 \mathrm{~mm}$, inducing evapotranspiration to decrease and reach its lowest level (only $12.4 \mathrm{~mm}$ ).

Although actual evapotranspiration decreased as a consequence of low net precipitation, the Etr/NP ratio increased with drought severity. Analyzing the SPEI, one can observe an increment in Etr/NP as the drought intensifies (i.e., SPEI becomes more negative) (Figure 5a), which indicates a greater proportion of water returning into the atmosphere. This is even more concerning in summer (December-February) since Etr/NP presented a straight relationship with summer droughts $(r=0.8984)$. This relationship suggests that the soil-plant-atmosphere continuum is more sensible to a water deficit during summer (wet season) than to a deficit in the hydrological year scale $(r=0.6561)$. Zhang et al. (2017) observed an increase in tree mortality with drought severity for different forest types over a monthly scale. However, tropical forests in Amazonia and Borneo have demonstrated to be adapted to small time-scale droughts due to some deciduous characteristics (Zhang et al., 2017). Semi-deciduous Atlantic forests are adapted to dry periods because of the presence of dry-affiliated species and the leaf shedding mechanism (Williams; Bunyavejchewin; Baker, 2008), which aid trees to save water and energy throughout rainless periods.

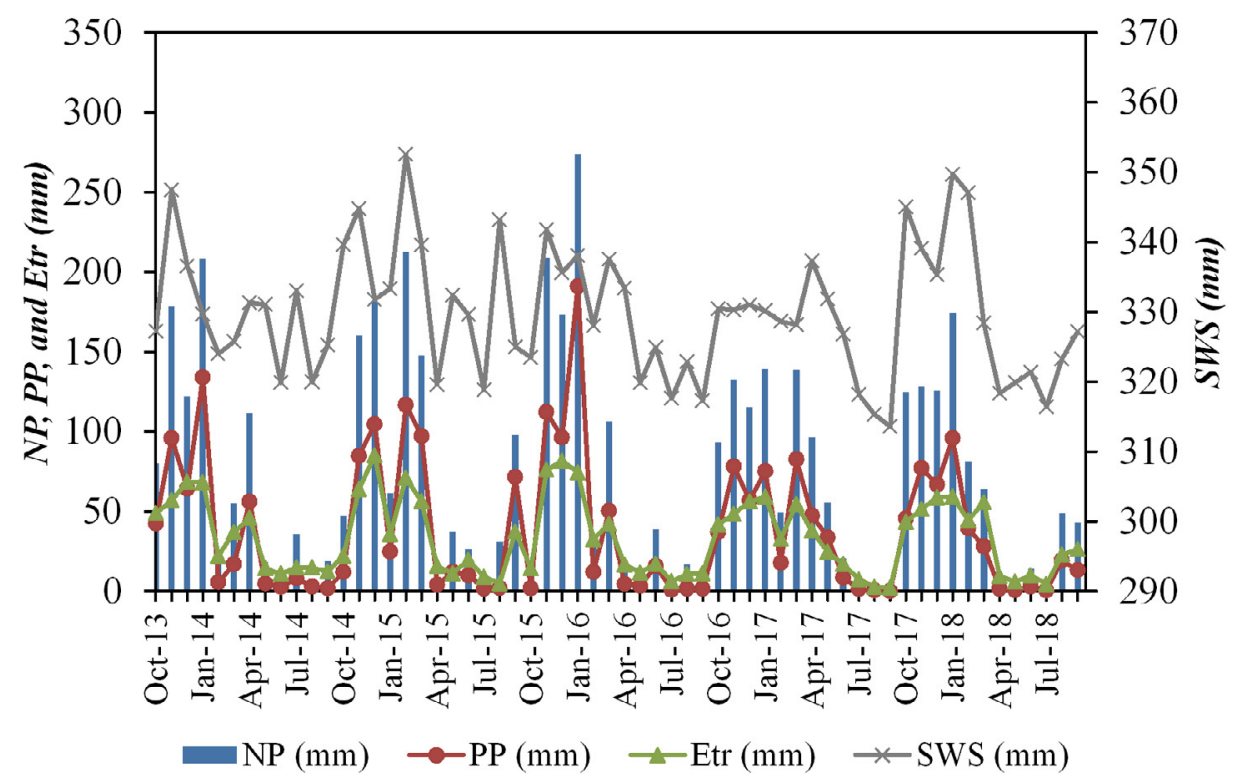

Figure 4: Monthly water balance of the Atlantic forest stand describing the net precipitation (NP), the potential percolation (PP), the actual evapotranspiration (Etr), and the soil water storage (SWS) simulated by Hydrus-1D throughout the five hydrological years (2013-2014, 2014-2015, 2015-2016, 2016-2017, and 2017-2018). 


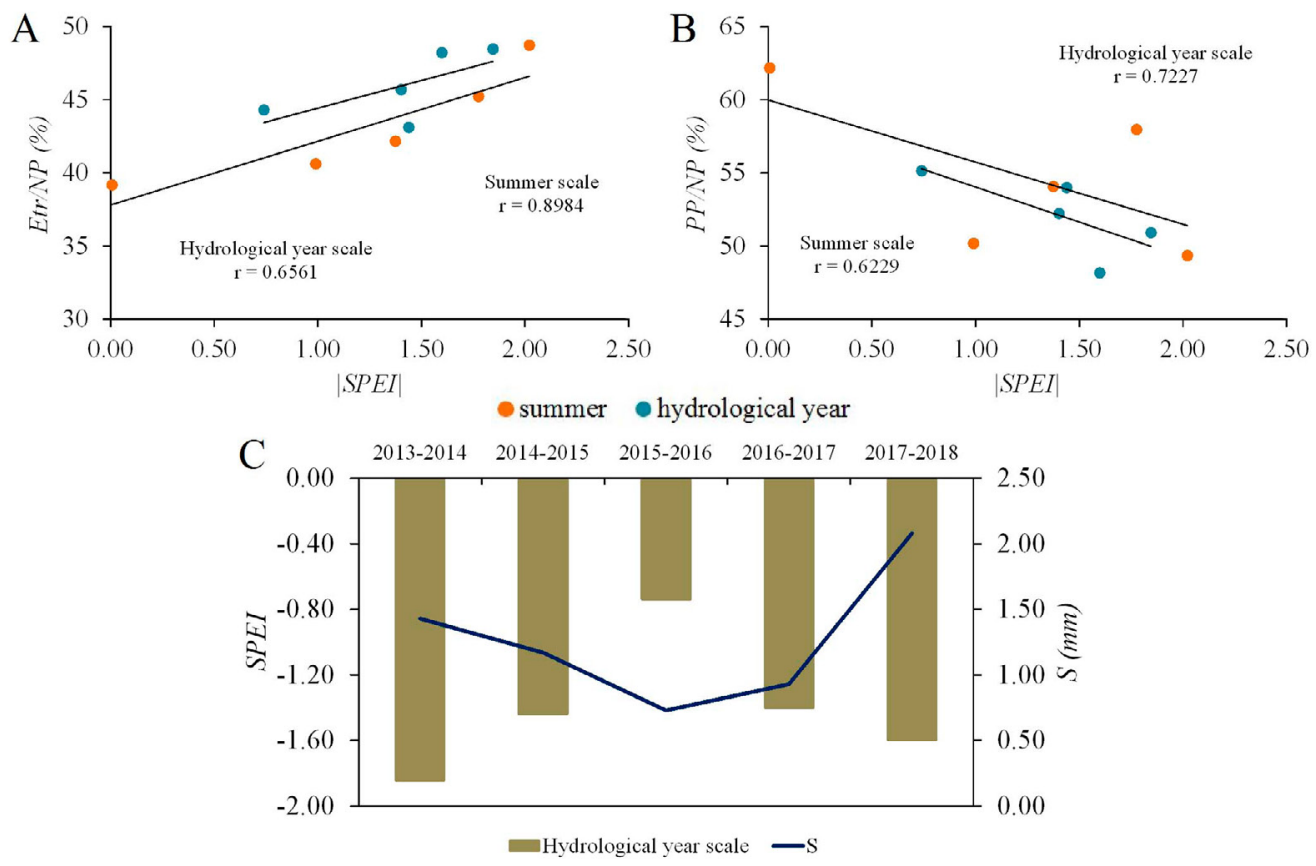

Figure 5: Relationship between (A) Etr/NP and SPEI (taken as absolute numbers), (B) PP/NP and SPEI, and (C) canopy storage capacity response to droughts in the hydrological year scale. Etr: actual evapotranspiration; NP: net precipitation; PP: potential percolation; SPEI: the Standardized Precipitation-Evapotranspiration Index; S: canopy storage capacity; r: Pearson correlation coefficient.

The semi-deciduousness could be assessed by the fluctuation of the canopy storage capacity (S) (Gash; Morton, 1978) (Figure 5c) since it encompasses the canopy structures (e.g., leaves, stems, twigs, and branches) that are able to intercept rainfall. The Atlantic forest remnant responded to droughts with a two-year time lag as it attained the lowest $\mathrm{S}$ in 2015/2016 (after the severe drought of 2013/2014) and recovered it in 2017/2018 (after the near normal 2015/2016), which indicates that some trees direct their efforts to recovery the canopy structure as a response to biomass losses after severe droughts (Rowland et al., 2018). This behavior highlights the delay of leaf shedding strategies, which requires other mechanisms to deal with sudden changes in the weather pattern (i.e., summer droughts) since soil water deficit may cause hydraulic failure, and therefore increases tree mortality (Rowland et al., 2015). The holding water capacity of the Oxidic Latosols maintained the soil water storage even for the driest summer (Figure 4), which guaranteed the evapotranspiration to be close to those of near normal summers (2015/2016 and 2017/2018) (Figure 4). Therefore, previous rainy months summed to some rainfall events are important to keep the physiological functions of the Atlantic forest remnant in dry summers.
Moreover, the effects of consecutive dry years demand further investigation because forests suffer from accumulated physiological damage (Anderegg et al., 2020). The effects of consecutive droughts on soil water availability may cause species shifting, decrease tree growth, and increase mortality (Rahman; Islam; Bräuning, 2019; Rowland et al., 2015; Zhang et al., 2017), leading to changes in the carbon sequestration dynamics (Anderegg et al., 2020). Understanding the connections between forest and hydrology is mandatory since forests' responses to drought are driven by changes in water availability (Broedel et al., 2017; Markewitz et al., 2010), as well as the water yield in a forested watershed is driven by both climate and forest characteristics (Teixeira et al., 2021).

\section{Potential percolation (PP)}

The increased demand for evapotranspiration negatively impacted the water percolation (Figure 4) since drought intensification decreased the potential percolation in the studied Atlantic forest remnant (Figure $5 b)$. The simulated percolation ranged from $392 \mathrm{~mm}$ to $542 \mathrm{~mm}$ throughout the five hydrological years (Figure 4) and is similar to those observed by Mello et al. (2019) (in 
a climatological normal year) in a watershed dominated by Atlantic forest in the Mantiqueira range. However, the simulated percolation cannot be accounted for as recharge because only the $1.0 \mathrm{~m}$ depth profile was assessed in the water balance and some tree species are adapted to uptake water from deeper layers. For instance, some Amazonian species uptake water up to $11.5 \mathrm{~m}$ depth when stressful conditions are present (Markewitz et al., 2010) and only a parcel of the potential percolation reaches the water table. Thus, to highlight the impacts of droughts on groundwater recharge further studies should consider the root water uptake from deeper layers in semi-deciduous Atlantic forests.

\section{CONCLUSIONS}

Although uncertainties could be observed in the calibrated parameters, the precision statistics (RMSE, ER, and NS) indicated an adequate performance of Hydrus-1D in modeling the water balance under drought conditions. The soil moisture is mostly driven by the spatial variability of net precipitation and the soil saturated hydraulic conductivity (Ks). Moreover, preferential pathways are likely the cause of the uncertainty in the calibrated Ks because they are not accounted for in the simple form of Richard's equation. The Atlantic forest remnant responded differently to summer and hydrological year time-scale droughts. The water deficit during summer increased the proportion of water transferred into the atmosphere and decreased the potential percolation in the wet season. The semi-deciduous characteristics cause changes in the canopy structure after drought episodes in a delayed process since leaf shedding and canopy recovering presented a two-year time lag.

\section{ACKNOWLEDGEMENTS}

We acknowledge CAPES [grant number 88882.306661/2018-01], CNPq [grant number 401760/20162], and FAPEMIG [grant number PPMX-545/18] for supporting and funding this work.

\section{REFERENCES}

AGUIRRE-GUTIÉRREZ, J. et al. Drier tropical forests are susceptible to functional changes in response to a longterm drought. Ecology Letters, 22(5):855-865, 2019.

ALLEN, R. G. et al. Crop evapotranspiration - Guidelines for computing crop water requirements: FAO Irrigation and drainage paper 56. Rome, Italia: Food and Agriculture Organization, 1998. 333p.
ANDEREGG, W. R. L. et al. Divergent forest sensitivity to repeated extreme droughts. Nature Climate Change, 10:1091-1095, 2020.

ANDERSON, T. W.; DARLING, D. A. Asymptotic theory of certain "goodness of fit" criteria based on stochastic processes. The Annals of Mathematical Statistics, 23(2):193-212, 1952.

ANDERSON, T. W.; DARLING, D. A. A test of goodness of fit. Journal of the American Statistical Association, 49(268):765-769, 1954.

ÁVILA, L. F. et al. Partição da precipitação pluvial em uma microbacia hidrográfica ocupada por Mata Atlântica na serra da Mantiqueira, MG. Ciencia Florestal, 24(3):583595, 2014.

BRAGA, R. M. et al. Physical attributes of distroferric red latosol under four eucalypt species over the long term. Ciência e Agrotecnologia, 37(4):313-322, 2013.

BROEDEL, E. et al. Deep soil water dynamics in an undisturbed primary forest in central Amazonia: Differences between normal years and the 2005 drought. Hydrological Processes, 31(9):1749-1759, 2017.

CHEN, M.; WILLGOOSE, G. R.; SACO, P. M. Spatial prediction of temporal soil moisture dynamics using Hydrus-1D. Hydrological Processes, 28(2):171-185, 2014.

COELHO, C. A. S. et al. The 2014 southeast Brazil austral summer drought: Regional scale mechanisms and teleconnections. Climate Dynamics, 46:3737-3752, 2016.

GASH, J. H. C.; MORTON, A. J. An application of the Rutter model to the estimation of the interception loss from Thetford Forest. Journal of Hydrology, 38(1-2):49-58, 1978.

JUNQUEIRA, R. et al. Hydrological responses to drought occurrences in a brazilian savanna basin. Resources, 9(10):1-11, 2020.

JUNQUEIRAJUNIOR, J. A. et al. Rainfall partitioning measurement and rainfall interception modelling in a tropical semideciduous Atlantic forest remnant. Agricultural and Forest Meteorology, 275:170-183, 2019.

JUNQUEIRA JUNIOR, J. A. et al. Time-stability of soil water content (SWC) in an Atlantic Forest - Latosol site. Geoderma, 288:64-78, 2017.

LUCAS, J. F. R. et al. Curva de retenção de água no solo pelo método do papel-filtro. Revista Brasileira de Ciência do Solo, 35(6):1957-1973, 2011.

MARKEWITZ, D. et al. Soil moisture depletion under simulated drought in the Amazon: Impacts on deep root uptake. New Phytologist, 187(3):592-607, 2010. 
MELLO, C. R. et al. Water balance in a neotropical forest catchment of southeastern Brazil. Catena, 173:9-21, 2019.

MUALEM, Y. A new model for predicting the hydraulic conductivity of unsaturated porous media. Water Resources Research, 12(3):513-522, 1976.

OLIVEIRA, V. A. et al. Spatiotemporal modelling of soil moisture in an Atlantic forest through machine learning algorithms. European Journal of Soil Science, 13123:1-19, 2021.

OLIVEIRA, V. A. et al. Assessment of climate change impacts on streamflow and hydropower potential in the headwater region of the Grande river basin, Southeastern Brazil. International Journal of Climatology, 37(15):5005-5023, 2017.

RAHMAN, M.; ISLAM, M.; BRÄUNING, A. Species-specific growth resilience to drought in a mixed semi-deciduous tropical moist forest in South Asia. Forest Ecology and Management, 433:487-496, 2019.

RODRIGUES, A. F. et al. Modeling canopy interception under drought conditions: The relevance of evaporation and extra sources of energy. Journal of Environmental Management, 292:e112710, 2021.

RODRIGUES, A. F. et al. Soil water content and net precipitation spatial variability in an Atlantic forest remnant. Acta Scientiarum.Agronomy, 42:e43518, 2020.

ROWLAND, L. et al. Shock and stabilisation following longterm drought in tropical forest from 15 years of litterfall dynamics. Journal of Ecology, 106(4):1673-1682, 2018.

ROWLAND, L. et al. Death from drought in tropical forests is triggered by hydraulics not carbon starvation. Nature, 528:119-122, 2015.

SALEMI, L. F. et al. Land-use change in the Atlantic rainforest region: Consequences for hydrology of small catchments. Journal of Hydrology, 499:100-109, 2013.

ŠIMUNEK, J.; VAN GENUCHTEN, M. T.; ŠEJNA, M. Development and applications of the Hydrus and Stanmod software packages and related codes. Vadose Zone Journal, 7(2):587-600, 2008.

ŠIMUNEK, J. et al. Review and comparison of models for describing non-equilibrium and preferential flow and transport in the vadose zone. Journal of Hydrology, 272(1-4):14-35, 2003.

SOUZA, C. R. et al. Long-term ecological trends of small secondary forests of the atlantic forest hotspot: A 30- year study case. Forest Ecology and Management, 489:1-9, 2021.

TEIXEIRA, G. M. et al. Regeneration of tropical montane cloud forests increases water yield in the Brazilian Atlantic Forest. Ecohydrology, 14:e2298, 2021.

TERRA, M. C. N. S. et al. Stemflow in a neotropical forest remnant: vegetative determinants, spatial distribution and correlation with soil moisture. Trees, 32:323-335, 2018.

TERRA, M. C. N. S. et al. Tree dominance and diversity in Minas Gerais, Brazil. Biodiversity and Conservation, 26:21332153, 2017.

TURKELTAUB, T. et al. Examination of groundwater recharge with a calibrated/validated flow model of the deep vadose zone. Journal of Hydrology, 522:618-627, 2015.

VAN GENUCHTEN, M. T. A numerical model for water and solute movement in and below the root zone. Unpublished Research Report. U. S. Salinity Laboratory, USDA, ARS, Riverside, USA, 1987. 66p.

VAN GENUCHTEN, M. T. A closed-form equation for predicting the hydraulic conductivity of unsatrated soils. Soil Science Society of America Journal, 44(5):892-898, 1980.

VENTRELLA, D. et al. Assessment of the physically-based Hydrus-1D model for simulating water fluxes of a Mediterranean cropping system. Water, 11(8):e1657, 2019.

VICENTE-SERRANO, S. M.; BEGUERÍA, S.; LÓPEZ-MORENO, J. I. A multiscalar drought index sensitive to global warming: The standardized precipitation evapotranspiration index. Journal of Climate, 23(7):1696-1718, 2010.

WILLIAMS, L. J.; BUNYAVEJCHEWIN, S.; BAKER, P. J. Deciduousness in a seasonal tropical forest in western Thailand: Interannual and intraspecific variation in timing, duration and environmental cues. Oecologia, 155:571582, 2008.

WORLD METEOROLOGICAL ORGANIZATION - WMO. Standardized precipitation index user guide. 2012. Available in: <http://www.wamis.org/agm/pubs/SPI/ WMO_1090_EN.pdf $>$. Access in: August, 17, 2020.

ZHANG, Q. et al. Relationship of climatic and forest factors to drought- and heat-induced tree mortality. PLoS ONE, 12(1):1-17, 2017.

ZHANG, Y. et al. The preferential flow of soil: A widespread phenomenon in pedological perspectives. Eurasian Soil Science, 49(6):661-672, 2016. 